\title{
Lumen
}

Selected Proceedings from the Canadian Society for Eighteenth-Century Studies

Travaux choisis de la Société canadienne d'étude du dix-huitième siècle

\section{Reading Austen's Lady Susan as Tory Secret History}

\section{Rachel Carnell}

Volume 32, 2013

URI : https://id.erudit.org/iderudit/1015480ar

DOI : https://doi.org/10.7202/1015480ar

Aller au sommaire du numéro

Éditeur(s)

Canadian Society for Eighteenth-Century Studies / Société canadienne d'étude du dix-huitième siècle

ISSN

1209-3696 (imprimé)

1927-8284 (numérique)

Découvrir la revue

Citer cet article

Carnell, R. (2013). Reading Austen's Lady Susan as Tory Secret History. Lumen,

32, 1-16. https://doi.org/10.7202/1015480ar d'utilisation que vous pouvez consulter en ligne.

https://apropos.erudit.org/fr/usagers/politique-dutilisation/ 


\title{
Reading Austen's Lady Susan as Tory Secret History
}

\author{
Rachel Carnell \\ Cleveland State University
}

Anne Elliot famously observes to Captain Harville in Jane Austen's Persuasion that men have the advantage over women in having written the literature that depicts women as fickle. Austen was also critical of male-authored national history, including Oliver Goldsmith's Whiggish History of England, which she mocked in notes scribbled in the margin of the family's copy and satirized in her own unabashedly Tory "History of England," which she wrote when she was sixteen. ${ }^{1}$

While most histories of England available in Austen's time were written by men, two prominent eighteenth-century women wrote widely read histories of the "Glorious" Revolution of 1688 , an event central to Whig historiography. Delarivier Manley’s best-selling Tory secret history Secret Memoirs and Manners of ... the New Atalantis (1709) retells the political events of 1688-89 as the work of ungrateful courtiers, including John Churchill, subsequently the Duke of Marlborough, who put their own ambition above the binding bonds of chivalry that should have prevented them from deserting James II. Manley's work, which satirizes the Duke and Duchess of Marlborough at the height of their power, may be read against the Duchess's subsequent Whiggish version of the same events in her An Account of the Conduct of the Dowager Duchess of Marlborough (1742). Although we do not know whether Austen had read Manley's and Marlborough's narratives, she would have been familiar with the partisan political

1. This essay was adapted from my 2011 CSECS presentation, "The Politics of Friendship: Manley, Marlborough, and Austen as Partial and Prejudiced Historians.” 
discourses that they depicted. Moreover, her depiction of false friendship in Lady Susan, a novel that hearkens back to the eighteenth century through its epistolary structure, offers an echo of the competing Tory and Whig discourses of friendship and political loyalty first articulated by her equally biased and partisan female predecessors in historiography.

What is immediately striking about Austen's Lady Susan is how much it feels like an eighteenth-century text, both because it is epistolary and because it has a devious and fully unrepentant heroine who recalls, for example, the heroines of Eliza Haywood's Fantomina (1725) or Anti-Pamela (1740). Most biographers have assumed that Austen wrote Lady Susan during the mid 1790s although the extant fair copy is on paper some of whose leaves have a watermark of 1805 . Whether or not Austen first drafted the novel in the late eighteenth or the early nineteenth century, she was clearly still interested in the project at a time when she had already drafted several other novels that, at least in their final published form, have a much more nineteenth-century feel to them, with morally upright heroines and sophisticated third-person narrators. Many critics have responded to Lady Susan as a depiction of female power, and some have considered it in light of the politics of the French Revolution. Other scholars have considered the novel's stylistic debt to earlier eighteenth-century genres; however, no one has yet suggested that Austen may have chosen to hearken back stylistically to the eighteenth century in order to comment on early eighteenthcentury politics. ${ }^{2}$ Nevertheless, several names in the novel allude to

2. Janet Todd and Linda Bree summarize over two centuries of criticism in their introduction to Lady Susan in Later Manuscripts, ed. Janet Todd and Linda Bree, The Cambridge Works of Jane Austen, ed. Janet Todd, (Cambridge: Cambridge University Press, 2005-o8), lv-lxiii. Marilyn Butler aligns the heroine with the male seducers of the anti-Jacobin period in Jane Austen and the War of Ideas (Oxford: Clarendon Press, 1975), 122. In his preface to Jane Austen's Lady Susan (New York: Garland Publishing, 1989), A. Walton Litz sees the novel as "a move back into the more familiar world of eighteenth-century satire and comedy," concluding that Austen was drawing from literature, rather than personal experience. Mary Favret analyzes the novel in terms of Pitt's national surveillance policies in Romantic Correspondence: Women, Politics, and the Fiction of Letters (Cambridge: Cambridge University Press, 1993), 142. In Rethinking Jane Austen's Lady Susan: The Case for Her 'Failed' Epistolary Novella (Lewiston, NY: Edwin Mellen Press, 2010), David Owen argues that Austen faced a challenge in articulating her anti-Jacobinism through an epistolary format that was deployed to good effect by both Jacobin and anti-Jacobin writers (98). 
important figures from the reign of Queen Anne, and Austen herself, as is indicated in her marginal notes to Goldsmith, was perfectly familiar with a standard Tory critique of that era.

One significant thread in Lady Susan is the theme of women deceiving other women. In Pride and Prejudice, Elizabeth Bennet is almost entirely honest with her sister Jane, and in Sense and Sensibility, Elinor largely tells Marianne the truth, although the heroines of both novels do withhold information at key points in order to protect their sisters from an emotional shock. By contrast, in Lady Susan, the heroine glibly deceives almost everyone around her, including her own daughter, her suitors, her sister- and brother-in-law, and the husband of her best friend. She was also, it is rumored, unfaithful to her own husband, and is still, after his death, pursuing a flirtation with the married Mr. Manwaring.

As far as we can gather, however, Lady Susan does not deceive her close friend Mrs. Johnson in their correspondence; certainly the letters written to Alicia show a mercenary and unrepentant side to Susan's personality that the heroine eloquently disguises from the rest of her correspondents. However, by the end of the novel, Susan expresses little regret when Alicia explains that unless she breaks off her correspondence with Susan, her husband would never again take her to London, a pleasure she would not live without. Lady Susan's response is simply: "I yeild to the necessity which parts us. Under such circumstances you could not act otherwise." She adds, "[o]ur friendship cannot be impaired by it," suggesting that when Alicia becomes (through the death of her husband) as "independent" as she herself is, they will be united in the "same Intimacy as ever." ${ }^{3}$ However, in expressing no regret at the temporary loss of intimacy, Susan stands in stark contrast to Elizabeth Bennet, who confesses to her sister Jane after three month's apart: "Oh how I wanted you!"4 Rather than needing the comfort of a friend and confidant, Lady Susan takes comfort in her own self-love: "meanwhile, [I] can safely assure you that I never was more at ease, or better satisfied with myself \& everything about me, than at the present hour" (72).

3. Jane Austen, Lady Susan, The Cambridge Works of Jane Austen, 71-72.

4. Jane Austen, Pride and Prejudice, ed. Pat Rogers, The Cambridge Works of Jane Austen, 250. 
Austen has created a portrait of a woman for whom female friendship is as unnecessary as any feeling of love for her husband, a heroine who values her independence above her sentimental attachments, who manipulates others at will for her own financial necessity or comfort, a lady, in other words, who hearkens back to the portraits of the staunchly Whig, Sarah Churchill, Duchess of Marlborough, quondam friend and confidant of Queen Anne and focal point of much antiWhig satire, wherein she was often referred to as a certain "Great Lady."

Is it possible that Jane Austen, who was born over three decades after the death of the Duchess of Marlborough (1744) and six decades after the death of Queen Anne (1714), could have had any thought of this venerable Whig courtier while she was writing Lady Susan? Austen's decision to name the Vernon's family seat "Churchill," the family name of the Duke of Marlborough, would not in itself be convincing evidence. However, Austen also possibly alludes to another significant name in the life of the Duchess of Marlborough: Arthur Maynwaring, the Whig M.P., political pamphleteer and satirist. Is it mere coincidence that Lady Susan's rumored lover, Mr. Manwaring, has a name strikingly similar to that of the Duchess of Marlborough's close friend, confidant and self-styled political secretary, whom the Duchess nursed in his final fatal illness? We will never know for certain whether or not Austen was thinking of Sarah, Duchess of Marlborough while she was writing Lady Susan. However, reading the novel against the political backdrop of early eighteenth-century British politics is justified when we consider Austen's own response to the Revolution of $1688-89$ and its aftermath.

Jane Austen's Tory ideology has been rightly linked by Marilyn Butler and others to the anti-Jacobinism of her era. In a recent monograph on Lady Susan, David Owen follows standard critical tradition in interpreting the text as anti-Jacobin, even as he acknowledges the ideological conundrum Austen faced in working in an epistolary structure that "appealed to writers, particularly women, on either side of the Jacobin/anti-Jacobin divide." Yet even before the French Revolution had begun, the Austen family's long tradition of Toryism would have shaped the discourses of Austen's childhood. We see these

5. David Owen, Rethinking Jane Austen's Lady Susan, $9^{8 .}$ 
discourses at play in her delightfully satirical "The History of England, By a partial, prejudiced, \& ignorant Historian,” which gleefully articulates a youthful and unapologetic pro-Stuart stance. Austen sides with Mary, Queen of Scots, matriarch of future Stuart monarchs of England, and disparages Elizabeth I, loved by Protestant Whig historiographers. The young Jane Austen ends her brief satirical history with the execution of Charles I, gesturing to her own openly partisan bias:

I shall satisfy myself with vindicating him from the Reproach of Arbitrary and tyrannical Government with which he has often been Charged. This, I feel, is not difficult to be done, for with one argument I am certain of satisfying every sensible and well-disposed person whose opinions have been properly guided by a good Education-and this argument is that he was a Stuart. ${ }^{6}$

While Austen is certainly mocking with her glib Tory tone the glib Whiggism of Oliver Goldsmith's six-volume History of England, she nevertheless still suggests that in families in which the young are "properly guided by a good Education" a Tory (pro-Stuart) bias is inevitable.

This family discourse of Toryism is equally evident in the marginal notes Jane Austen added to the family copy of Goldsmith's History. Although Austen herself was born almost a century after the Revolution of 1688-89, she expresses strong and decided opinions about that political coup (an event she certainly does not term "Glorious") as well as about the reign of Queen Anne. In her marginal annotations to Goldsmith, Austen refers to William of Orange as "a Villain" and the Earl of Sunderland, who turned against James II as a "Bad Breed." Austen makes a snide comment about the behavior of Lord Delamere, the first of the nobility to embrace William's cause after the latter's landing at Torbay, in comparison to the calmer Toryism of Lord Godolphin.

Interestingly, Austen connects these noblemen from history to the characters of Delamere and Godolphin in Charlotte Smith's novel Emmeline (1788). Smith's calmer, more reflective suitor, Godolphin,

6. Jane Austen, "The History of England from the reign of Henry the $4^{\text {th }}$ to the death of Charles the $1^{\text {st" }}$ in Juvenilia, ed. Peter Sabor, The Cambridge Works of Jane Austen, 188-89. The bold typeface used in Sabor's edition reflects the thick, dark ink lines on this word in Austen's handwriting, as is evident in a facsimile edition.

7. Marginal note to Goldsmith, 4:32, reprinted in Juvenilia, ed. Sabor, 332. 
reflects the cautious Toryism of his real-life namesake, Sidney Godolphin, while Delamere sounds like a disloyal Whig. Austen scribbles in the margin: "I should have expected Delamere to have done so, for it was an action unsuited to Godolphin." ${ }^{\prime}$ In this allegorical reading, Austen inverts the usual terms of a secret history in which fiction incorporates recognizable characters from real political history: here, she reads Goldsmith's History as the fiction into which Smith's characters define the actual historical personages.

In her marginal glosses on Goldsmith's History, Austen makes clear that she admires Queen Anne as a Stuart but not as a defector to William and Mary in 1688. Goldsmith describes how Princess Anne and her husband, George of Denmark, "had followed the rest of [James II's] favourites" to "take part with the prevailing side." The young Austen responds in the margin: "Anne should not have done soindeed I do not believe she did." "The only way by which one might argue that Princess Anne did not defect from James II is to blame the influence of Lady Churchill (subsequently Duchess of Marlborough), who was well known to have accompanied Anne in her flight from Whitehall Palace, shortly after her husband and Anne's husband, Prince George of Denmark (usually believed to be following Churchill's strategic advice), had defected from James II's military encampment.

Judging from her marginal glossing of Goldsmith, Austen approved of Anne's behavior as monarch only after she, as Queen, broke with the Marlboroughs, who had been promoting Whig military policy in the War of Spanish Succession. In her marginal commentary, Austen interrogates the Whigs' instinctual distrust of the French during this period, answering Goldsmith's acknowledgement of France as the "peculiar object of the hatred of the Whigs" by describing the Whigs' hatred of France as being "without any reason."10 Austen also disparages Richard Steele's Whig pamphleteering during Anne’s reign. Goldsmith describes Steele's pamphlet The Crisis, in which "he bitterly exclaimed against the ministry" (i.e. Anne's Tory ministry of 1713), because of what he felt was the "danger of their bringing in the pre-

8. Marginal note to Goldsmith, 4:39, Juvenilia, 334 .

9. Marginal note to Goldsmith, 4:41, Juvenilia, 334.

10. Marginal note to Goldsmith, 4:49, Juvenilia, 335 . 
tender." Austen responds in her marginal scrawl: "It is a pity that he had not been better employed." 11

We may conclude, in other words, that Jane Austen was perfectly aware of the discourses of Tory propaganda written during the early eighteenth century. Her reading of historical personages in Goldsmith against the fictitious characters in Charlotte Smith's Emmeline also suggests that she was practiced in the eighteenth-century habit of reading allegorically. In expressing her distrust of Steele's Whig pamphleteering, moreover, Austen is aligning herself, with Steele's quondam friend but public opponent in the propaganda wars of Queen Anne's reign, Delarivier Manley, who mocked Steele mercilessly in her political secret histories, then joined with Jonathan Swift in the virulent propaganda battles between The Gazeteer, penned by Richard Steele, and The Examiner, begun by Jonathan Swift and continued briefly by Manley.

In her Secret Memoirs and Manners of ... the New Atalantis, Manley invents a scene in which John and Sarah Churchill anticipate the need for Lady Churchill to "carry Lady Olympia"-i.e. Princess Anne-away with her in her flight from court, in order to use her influence on Anne subsequently as the "Rock" she would "build" upon "for Fame, for Grandeur."12 In Manley's retelling of the events of the Revolution of 1688-89 as a Tory secret history, it is only because of Lady Churchill's-Madam de Caria's_- good Management" (2:230) of Princess Anne, that the latter defects from her father. For Tory propaganda writers, Anne was kind, generous, and loyal to her friends. These friends, including the Marlboroughs, in turn, were selfish and ungrateful and merely using their friendship with Anne in order to influence her politically for their own personal gain.

In Lady Susan, Austen's eponymous heroine and her friend Mrs. Johnson are equally ambitious (i.e. "Whiggish" - in the discourses of Toryism), equally self-centered, and equally indifferent to the feelings of others. Most readers of Lady Susan probably feel little concern at Susan and Alicia's renunciation of their friendship, since each is selfish enough to put personal convenience and ambition above the demands

11. Marginal note to Goldsmith, 4:185, Juvenilia, 336 .

12. Delarivier Manley, Secret Memoirs and Manners ... of the New Atalantis, ed. Rachel Carnell, in The Selected Works of Delarivier Manley, 5 vols., ed. Rachel Carnell and Ruth Herman (London: Pickering \& Chatto, 2005), 2:230. 
of sentimental attachment. However, we worry about Lady Susan's influence on those around her who are less ruthless and self-serving, particularly her own daughter, whom she tries to marry to a wealthy but insipid baronet while she herself tries to ensnare the man Frederica actually loves. Whether or not Jane Austen had Sarah, Duchess of Marlborough, in mind when she created Lady Susan, another echo appears here to that "Great Lady" of Tory propaganda from the age of Anne. The Duchess of Marlborough was known for marrying her daughters into the families of other powerful Whigs, at ages when the girls themselves would have been too young to have been able to object.

Sarah Churchill herself had married the man she loved-against family objections-and Sarah and John rose together through her friendship with Princess Anne and his military skill and to the rank of Duke and Duchess of Marlborough. Once elevated to this rank, however, the Duchess did not allow her own daughters the same level of independence she herself had achieved; instead, with little regard for their own feelings, she married every one of them, as teenagers, into prominent Whig families. She arranged a marriage for her eldest daughter, Henrietta, to Francis Godolphin, the son of Sarah and John's close friend and political ally, Sidney Godolphin, Lord Treasurer to Queen Anne. Henrietta's subsequent love affair with the playwright William Congreve infuriated her mother, who nevertheless seems not to have regretted having arranged the marriage. Her second daughter, Anne, was married to Robert, third Earl Sunderland, whose abrasiveness was well known and who was not trusted by either Anne or Sarah to have custody of the children following Anne's untimely death. The Marlboroughs engaged their fourth daughter, at age fourteen, to John, son of the powerful Whig politician Ralph Montagu, who was given a dukedom by Queen Anne as part of the political and monetary negotiations for that marriage. In later life the Duchess of Marlborough herself would observe of her middle-aged son-in-law: "All his talents lie in things only natural in boys of fifteen years old ... to get people into his garden and wet them with squirts, and to invite people to his country houses and put things in their beds to make them itch."13 The

13. Cited in Bonamy Dobrée, Three Eighteenth-Century Figures: Sarah Churchill, John Wesley, Giacomo Casanova (Oxford: Oxford University Press, 1962), 61. 
Duchess, in other words, was cynically aware of the shortcomings of her sons-in-law, but like Austen's Lady Susan, the Duchess had put ambition over the happiness of her own children.

The Duchess of Marlborough, who quarreled continuously with all of her married daughters except Anne, clearly had a difficult time sustaining friendships with women. Like Austen's Lady Susan, she seems to have been on more comfortable footing in her close friendships with men, especially her confidants and political allies Sidney Godolphin and Arthur Maynwaring. However, in her published Account of her own conduct, the Duchess Dowager of Marlborough contrasts the younger Princess Anne's earlier professions of love and devotion to her to the older Queen Anne's colder and more indifferent treatment of her. She begins her Account with an analysis of friendship in which she observes that

Kings and princes, for the most part, imagine they have a dignity peculiar to their birth and station, which ought to raise them above all connexion of friendship with an inferior. Their passion is to be admired and feared, to have subjects awfully obedient, and servants blindly obsequious to their pleasure. Friendship is an offensive word; it imports a kind of equality between the parties; ${ }^{14}$

In distinguishing Anne from the usual sort of prince in that she was happy to make herself, as "Mrs. Morley," the equal of her epistolary correspondent "Mrs. Freeman" (pseudonyms Anne had desired to reduce the formality of their correspondence), the Duchess casts Anne's initial notion of friendship in Whig terms. Subsequently in her Account, Marlborough critiques Anne's eventual loss of regard for her as a disloyalty inconsistent with her earlier affection, unfairly judging Anne, whom she knew to be a staunch Tory, guilty of not maintaining a Whiggishly equalizing ideal of friendship.

The vehemently partisan and self-interested "Great Lady" of antiWhig propaganda, who, in her support of the Whigs and the War of Spanish Succession considered herself greatly the intellectual and political superior of the Queen, seems not to have listened to her monarch's occasionally well-turned satirical quips, couched as they

14. Churchill, Sarah, Duchess of Marlborough, An Account of the Conduct of the Dowager Duchess of Marlborough (London: printed by James Bettenham for George Hawkins, 1742), 13 . 
were in the humble discursive cloak of Tory love and devotion. Very early in her reign, for example, Queen Anne counseled the then Countess of Marlborough that she was "mightily mistaken in [her] notion of a true whig"; in the Queen's view, the fine qualities that Sarah ascribed to the Whigs rightly belonged to the "church" or Tory "party."15 About a year later, Anne reiterated that "when Sarah came to know the Whigs better, she would find they were not all they professed to be."16

But the Duchess of Marlborough, who could not tolerate a difference of opinion between herself and her intimate friends, continued to let the Queen know that she felt she was putting the nation and the Protestant religion in danger by taking advice from the Tories. Gradually, as the two women grew more estranged and the Duchess of Marlborough continued to send the Queen almost daily harangues of Whiggish propaganda, Queen Anne stopped responding to the Duchess's diatribes. When Sarah finally begged for what would be a final, tearful interview in April 1710, the Queen's only response to her impassioned and defensive pleadings was to repeat, over and over again, "you may put it in writing." 17 Anne, who had an excellent memory, was not adept at putting her thoughts together quickly, unlike the Duchess who formed her thoughts rapidly and spoke her mind without hesitation, priding herself on her frankness. However, by the spring of 1710, Queen Anne had seen the power of Delarivier Manley's best-selling secret histories in mocking the Whigs, the Marlboroughs, and their allies. She had seen the Earl of Sunderland, the Marlboroughs' abrasive and staunchly Whig son-in-law, overreach himself in his prosecution of Manley and the Tory divine Henry Sacheverell, and she had dismissed him from office without offering any explanation or justification. Queen Anne had finally realized that all she needed to do was to refuse to say anything directly to the Marlborough clan and that Manley, Swift and the rest of the Tory propaganda writers would articulate her complaints for her. Almost a century after her death, Queen Anne's Whig opponents appear to have been attacked once

15. Marlborough, Account of the Conduct, 128.

16. BL Add. MS 6416, fo. 95: Anne to SM [?16 June 1703], paraphrased by Frances Harris in A Passion for Government: The Life of Sarah Churchill, Duchess of Marlborough (Oxford: Oxford University Press, 1991), 91.

17. Marlborough, Account of the Conduct, 239. 
more in an epistolary novel by a young Tory satirist, as yet unknown to the public.

$$
\text { is is is }
$$

We do not know whether or not Austen had read Manley's New Atalantis, nor how much thought she might have given to the Duchess of Marlborough's role during the reign of Queen Anne. However, Austen might have remembered Samuel Johnson's reference to the Duchess of Marlborough as "a late female minister of state," in an issue of The Rambler on the topic of friendship. In this essay, Johnson faults the Duchess for manipulating Queen Anne into revealing her secrets by citing Montaigne's assertion that divulging a secret to a friend is not really a breach of trust, since "a man and his friend" are "virtually the same” person. Johnson further condemns Marlborough for being "shameless enough to inform the world," in her published Account, of having done this. ${ }^{18}$ In other words, whatever else Austen knew about the first Duchess of Marlborough, she probably knew of her as a shamelessly manipulative and false friend to Queen Anne.

Whether or not Austen had Sarah, Duchess of Marlborough in mind when she was writing Lady Susan, we are invited to read Austen's Lady Susan as a secret history in part because Austen's juvenilia often included identifiable references to specific persons. As Brigid Brophy has pointed out, the "Mr. Johnson" who appears on the first page of "Jack and Alice" may be read as the clergyman granted a Leigh family living that many of the Austen and Leigh families probably thought ought to have been given to a member of the extended family. ${ }^{19}$ The character of Lady Susan, of course, was probably based in part on Austen's cousin Eliza de Feuillide, who was flirting simultaneously with two of Austen's older brothers in the winter of $1794-95 .{ }^{20}$ However, eighteenth-century fiction that Austen knew well, by Samuel Richardson

18. Samuel Johnson, The Rambler No. 13, May 1, 1750, The Yale Edition of the Works of Samuel Johnson, vol. 3, ed. W. J. Bate and Albrecht B. Strauss (New Haven: Yale University Press, 1969), 71.

19. Brigid Brophy "Jane Austen and the Stuarts" in Critical Essays on Jane Austen, ed. B. C. Southam (London: Routledge and Kegan Paul, 1968), 22-24. lii.

2o. Janet Todd and Linda Bree, introduction to Lady Susan, Later Manuscripts, 
and others, "assumed and enacted allegorical ways of knowing" without necessarily insisting on a single set of referents, as Toni Bowers has pointed out. ${ }^{21}$ Bowers does not refer specifically to the category of the secret history in her analysis of the politics of seduction narratives. Nevertheless, in reference books that would have been found on library shelves in Austen's time, the term "anecdote" was still described as synonymous with the political secret history. In his Cyclopedia (1728), Ephraim Chambers defines "anecdotes," or "anecdota," as the term used by "some authors" to denote "secret history"; he specifically refers to Procopius's Anecdota, which he "published against Justinian and his wife Theodora." 22 This definition is echoed in abbreviated form in Samuel Johnson's Dictionary, with the emphasis on something as yet unpublished-as Austen's Lady Susan would remain for a century after it was written. As is suggested by her reading of several figures in Goldsmith's History as characters in a novel by Charlotte Smith, Austen was prepared to read both fiction and history in simultaneously personal and allegorical terms.

Late seventeenth- and eighteenth-century secret histories and memoirs followed the tradition of Procopius in political secret histories modeled on the idea of the anecdote, or "la petite histoire," that recounted court gossip, usually sexual in nature, so as to tarnish the reputations of those who planned the events that shaped the grand narratives of history. As Lionel Gossman has demonstrated, the structure of many political secret histories was intentionally anecdotal: the power of the anecdote or the "little history," was that it often contradicted the other side's grand historical narrative. ${ }^{23}$ Annabel Patterson explains that, as the readers and writers of these anecdotal secret histories well understood, "sexuality is merely one of the tools of political strategy," and can represent monarchical tendencies that, at least in the minds of Whig writers, "directly interfere with parliamentary government." ${ }^{4}$

21. Toni Bowers, Force or Fraud: British Seduction Stories and the Problems of Resistance, 1660-1760 (Oxford: Oxford University Press, 2011), 293-94.

22. Ephraim Chambers, Cyclopeedia, or, An Universal Dictionary of Arts and Sciences (London: Printed for J. and J. Knapton et al., 1728), 2 vols., 1:87.

23. Lionel Gossman, "Anecdote and History," History and Theory 42 (May 2003): 143.

24. Annabel Patterson, Early Modern Liberalism (Cambridge: Cambridge University Press, 1997), 194-95. 
Whig secret histories written during the reign of Charles II often deployed salacious anecdotes about either the Duchess of Cleveland or the Duchess of Portsmouth to indicate these powerful women's influence over Charles II, an influence emblematic of the influence of the French Catholic monarch over that English sovereign. Such secret histories proliferated during the years leading up to the Revolution of 1688-89 and continued in popularity, justifying that Revolution, over the next few decades. Although the genre is best known for its contributions to Whig historiography, as Patterson suggests, Delarivier Manley was clearly inverting standard Whig stories about the Duchess of Cleveland in her Tory Secret Memoirs of ... the New Atalantis. Rather than using a sensuous scene with Cleveland to tarnish the image of Charles II, she deploys such scenes to highlight the ingratitude and disloyalty of the Duke of Marlborough, who not only betrayed the monarch who "tenderly lov'd him" but who continued, through the reign of Anne, to turn his back on his own party by pursuing a "perpetual Foreign War." 25 Manley's critique of the Whig-Marlborough foreign policy under Anne's reign is echoed in Austen's defense of Queen Anne's resistance to Whigs in the last years of Anne's reign in her marginal comments in Goldsmith's History. ${ }^{26}$

As Michael McKeon has observed, the secret history began a decline in importance following the death of Queen Anne in 1714, a decline he attributes to a gradual cultural "shift of normative weight from the public referent to the private reference-more precisely, the gradual absorption of the public realm's traditional priority and privilege by the realm of private experience." ${ }^{27}$ Moreover, as we can see in the mixed use of "secret memoir" or "novel" in title pages of Eliza Haywood's works from the 1720 s through the 1750 s, the genre gradually blurred into the more fluid category of the novel, which itself was still being read allegorically in the eighteenth century. Modern editors of Austen's Lady Susan liken the text to other first-person or epistolary novelistic "memoirs" from the mid to late eighteenth century, including Frances Sheridan's Memoirs of Miss Sidney Bidulph (1761), The Histories of Lady Frances S----, and Lady Caroline S---- (1763), and

25. The New Atalantis, 2: 31-32.

26. Marginal note to Goldsmith, 4:172-74, Juvenilia, 336.

27. Michael McKeon, The Secret History of Domesticity: Public, Private, and the Division of Knowledge (Baltimore: John Hopkins University Press, 2005), 621. 
Memoirs of Mary: A Novel (1794), the titles of which suggest a nod to earlier, more overtly political, secret histories. ${ }^{28}$

In 1735, two and a half decades after its first appearance, Manley's Secret Memoirs ... of The New Atalantis was serialized in The Weekly Novellist, a publication described as "Containing a select Collection of the best Novels, Moral, Political, \&c. with other Pieces of Love and Gallantry."29 If Jane Austen had read Manley's best-selling work, it is possible that she discovered it in such a collection of "novels" in a circulating library. It is also conceivable that an earlier edition of Manley's secret history (there were numerous printings between 1709 and 1720), which had found an appreciative audience with Jacobite families such as the Dukes of Beaufort, was on the shelf at the home of one of Austen's pro-Stuart relations: the Leighs had sheltered Charles I at Stoneleigh Abbey and had offered it as a refuge to Charles Edward Stuart in $1745 .{ }^{30}$ Whether or not Austen had ever encountered Manley's New Atalantis (either as a "novel" or a "secret history"), she would not have needed any instruction to read it allegorically.

Despite its decline in importance, the genre of the secret history still interested certain readers and writers in the late eighteenth and early nineteenth century because of the rich particularity of its narration. As April London has pointed out, the literary historian Isaac D'Israeli, although put off by the sexual scandal in works such as Manley's New Atalantis, found value in the anecdotal quality of secret histories. In Despotism; or, The Fall of the Jesuits: A Political Romance, Illustrated by Historical Anecdotes (1811), he envisions a new (old) way of writing history, by not describing "events and characters in the forms they now appear" and through which "we mistake the nature of things." For D'Israeli, in the new mode of history that he envisions, "Secret History is often a treasure under ground." 31

28. Todd and Bree, introduction to Lady Susan, lv.

29. This information is taken from an advertisement in the London Evening Post for Thursday 18 September 1735, cited in Rachel Carnell, A Political Biography of Delarivier Manley (London: Pickering \& Chatto, 2008), 237.

30. On Manley and the Beaufort family, see Carnell, A Political Biography of Delarivier Manley, 170. For Austen's and her family's support of the Stuarts, see Brigid Brophy "Jane Austen and the Stuarts," 21-38; for the reference to Stoneleigh Abbey, see M. A. Austen-Leigh, Personal Aspects of Jane Austen (London: J. Murray, 1920), 15-16.

31. Cited in April London, "Isaac D'Israeli and Literary History: Opinion, Anecdote, and Secret History in the Early Nineteenth Century" Poetics Today, 2005 
D'Israeli, who had watched the start of the French Revolution with sympathy for the revolutionaries, subsequently turned against it, and his taste for anecdotal historiography helped him articulate what April London describes as an "iconoclastic conservatism." His preference for the essay over the grand narrative of classical history allowed him to resist "hierarchies of knowledge" even as he chose to conserve classicism's "residual values" (358). In "Various Anecdotes Illustrating the History of Manners," D'Israeli incorporates an anecdote about a ninthcentury instance of anti-Semitic bigotry in order to shed light on nineteenth-century Britain's own anti-Semitism. As April London explains,

The closing paragraph, whose present tense, brevity, and aphoristic tone offer many signs of oblique reference (including one to continuing pogroms), smudges the boundary between the ninth century "age of bigotry" and the present moment. By directing our attention to this likeness, he makes the anecdote serve functions beyond the writing of the anti-institutional "counter histories" that Annabel Patterson describes as the genre's central contribution to early modern culture. ${ }^{32}$

For D'Israeli, then, the secret history offered a means of adding a counterpoint to the standard anti-Semitism of nineteenth-century British historiography.

Jane Austen, who might likewise be considered a conservative iconoclast-not as a Jewish intellectual in an anti-Semitic culture but as a young female writer without a classical education, working in a male world of letters-seems also to have gestured towards the genre of secret history in Lady Susan. Echoing the narcissism and disloyalty of a Whig courtier from the court of Queen Anne in her epistolary portrait, Austen gives a first-person voice to her boldly unrepentant heroine. Yet, this first-person voicing-typical in the genre of secret history, which was often cast as a packet of private letters intercepted and opened-paradoxically gives very little sense of the heroine's actual self. As Austen acknowledges when she shifts into her own narrator's voice at the end of her novel, her heroine will remains unknowable to her

Fall; 26 (3): 372. I was first introduced to April London's fascinating work on the history of anecdote in her presentation at the 2011 CSECS conference: "Unaccountable obliquity': Sterne's Tristram Shandy and Anecdote."

32. April London (374-75) is citing Patterson's Early Modern Liberalism (160). 
readers as long as they are required to rely on her own account of herself: "Whether Lady Susan was, or was not happy in her second Choice-I do not see how it can ever be ascertained-for who would take her assurance of it, on either side of the question?" (77). Austen continues, "The World must judge from Probability.-She had nothing against her, but her Husband \& her Conscience" (77).

We might view Lady Susan, in which Austen's narrator seems to acknowledge the limits of first-person narration (ironically doing so in the voice of her own first-person authorial narrator), as a stylistic precursor to her subsequent development of free indirect discourse. ${ }^{33}$ As Michael McKeon explains, Austen's Pride and Prejudice, which is full of letters, depicts interiority partly through the scenes of awakening that occur as a character reads and responds, often in free indirect discourse, to another character's letters. For McKeon, Austen's achievement in Pride and Prejudice signals a cultural shift accomplished across the previous century towards a new conception of interiority (717). Given that such a shift had been gradually emerging since about 1714 , however, it is significant that in the first decade of the nineteenth century Austen was still interested in crafting a heroine whose "true" self is difficult to discern.

Rather than assuming that she had not yet mastered the expression of "interiority" that she demonstrated in her later fiction, and rather than concluding that "Jane Austen clearly needed to move on,"34 we might instead understand Lady Susan as expressing Austen's continued interest in a style of political satire that resisted a novelistic expression of interiority. Austen's refusal to narrate any marks of Lady Susan's "Conscience" (which she mentions and therefore assumes must have existed) reveals the same taste for partisan caricature evident in her snide marginal comments in Goldsmith about Whig courtiers from earlier centuries. For those with a continued interest in Austen's iconoclastic version of Tory historiography, it is worth considering her interest-still largely secret to modern readers-in the anecdotal genre of secret history.

33. David Owen finds further evidence of Austen's move towards free indirect discourse in the moralizing "authorial narrative voice" of Catherine Vernon" (Rethinking Lady Susan, 35).

34. Todd and Bree, introduction to Lady Susan, lxiii. 